\title{
ICT Knowledge and Competence of Social Studies Educators in Ekiti State, Nigeria
}

\author{
Oluwagbohunmi, M. F. \\ Faculty of Education, \\ Ekiti State University, Ado-Ekiti, Nigeria
}

\begin{abstract}
This paper examined ICT knowledge and competence of Social Studies educators in Ekiti state, Nigeria. The study becomes imperative due to the significance ICT in national development since no nation can develop beyond its educational standard. The objective of this study was to determine the level of ICT literacy of the educators that are supposed to impart ICT knowledge into the students and to find out what constitute barriers to adoption of technology. The study employed descriptive design of the survey type. Using a sample of 150 respondents made up of Social Studies educators selected through simple random sampling technique from public secondary schools in Ekiti State, a self designed and validated instrument titled ICT Knowledge and Competence of Social Studies Educators (ICTKCSSE) was used for data collection. The instrument which consisted of structured questionnaire items was validated, tested for reliability and found usable for the study. Data generated were analysed using frequency count, simple percentage, means and standard deviation. The study found that social studies educators' knowledge of ICT was very low and that they lacked necessary skills for its usage. Barriers to adoption of technology were found to include erratic power supply and incompetence. The hypothesis showed no significant gender difference in the educators' level of ICT competence. Based on these findings, it was recommended that government should make computer literacy compulsory for all educators in secondary schools and ensure adequate and regular power supply.
\end{abstract}

\section{Introduction}

One of the objectives of ICT in Nigeria is to empower the youths with ICT skills and prepare them for global competitiveness and to integrate ICT into the mainstream of education and training. [6] stated that the modern educational techniques shall be increasingly used and improved upon at all levels of the education system and that educational training facilities shall continue to be expanded in response to social needs. ICT is one of the modern educational techniques and recent innovations being entrenched in the school system. Educators play significant role in the educational system and must not only be carried along but included in the planning since they are the main executors of government programmes in schools. In order to achieve the objectives of ICT, the educators must be computer literate. That is, they must be able to use computer effectively to impart knowledge. ICT is a globally recognized fastest tool for improving quality of learning, research, communication and administration. It is opened to everybody in the world society to enhance knowledge acquisition and keep people abreast of happenings in their environment.

In Social Studies, students are sensitised to happenings in their environments for them to be able to make positive impacts, to create room for better social interactions that can bring about a better society. [3] described this as an education that will direct and give students freehand and opportunities to make enquiries, investigate, discover, discuss, experiment and acquire experiences in order to make decisions on social issues and problems and find solutions to them. In view of this, Social Studies educators should create motivating learning environment through which students would be able to develop interest in using technology to aid learning. We live in a dynamic world where changes occur constantly in almost every facet of life. Since access to people and information anywhere in the world has become quicker, faster, cheaper and easier as a result of the use of phone, computer and internet, there is need to keep abreast of these changes which can quickly and easily be known through ICT. Keeping abreast of the changes however demands not only sourcing for information but the ability to maneuver facilities that are necessary for embracing technology in this digital age. This necessitates that individuals must know how to manipulate the computer, browse the internet, use CDROM, printers, scanning machines etc and how to locate, identify, download, print and effectively make use of information for improved functionality and survival of the society.

In order to develop students' computer skill, teacher must create a participative learning environment where his/her ICT skills, knowledge and practical experience will be used to support teaching and learning. It is the function of the teacher to provide learning opportunities to ensure students' active participation. Using technology in Social Studies will facilitate participative learning. ICT encourages student-centred and individualised learning as such student is able to learn anywhere, anytime and anyhow. The choice of what to learn becomes the sole prerogative of the leaners as they are exposed to variety of information coming from all parts of the world daily. Radio, television, handsets and 
computer can be very useful in social studies for discussions, debates data collection and data analysis respectively. Surfing the internet keeps students informed about emerging issues and trend of events. Students can also interact with other students in other parts of the world to clear some misconceptions about any aspect of culture or socialization process. While commenting on the import of ICT in learning, Cheta (2003) in [5] noted that when students and staff are equipped with the requisite computer skills, they would be in a position to perform their tasks better using fast and accurate communication network.

ICT is an important tool in the hands of teachers to improve teaching. It is therefore important for Social Studies teachers to understand and see the need to integrate ICT as a way of improving their teaching skills and enhancing their professional development. Teachers can get latest information on new research findings, share identified problems and solutions and discuss issues affecting teaching and learning of Social Studies through the internet. Social Studies enables students to acquire knowledge, skills, values, attitudes and competencies that develop them to effective citizens. It is the teacher that provides interesting and enjoyable learning environment to yield the desired result. For teachers to be able to expose students to learning activities using ICT, they too need to develop the required skills. They must be able to guide the students on appropriate use of ICT facilities for effective learning. This implies that the teachers need to develop ability to access the internet to search for and evaluate information as well as use quality information that is relevant to area of study.

\section{Literature Review}

ICT is a diverse set of technological tools and resources used to communicate, to create, disseminate, store and manage information [15]. ICT is simply defined by [17] as anything which allows us to get information, communicate with each other or to have effect on the environment using electronic or digital equipment. To [12], ICT is an electronic based system of information transmission, reception, processing and retrieval which has drastically changed the way we think and the way we live and the environment we live in. Adebayo and Adesope (2007) in [1] viewed ICT as the term used to describe the tools and processes to access, retrieve, store, organise, manipulate, produce, present and exchange information by electronic and other automated means. The use of internet and its technology has continued to have a remarkable influence on the way information is shared and promoted especially in the academic world, thus enhancing global collaboration among individuals and organisations [1]. Many learning materials are contained in CD-Rom and that world wide web (www) can best be described as a reservoir of modern resources and materials which can enable computer users to have access to a wide variety of information including magazines, archives, public and college library resources and current world news through the use of global internet. [20] gave reasons for integrating ICT into curricular and pedagogical structures to include:

- ICT commands improved access to and promote equity in education by providing educational opportunities to a greater number of people of all ages, sexes, climes, races, colours, women, girls and persons with disabilities

- It can enhance the quality of teaching and learning by providing access to a great variety of educational resources and by enabling participatory pedagogies

- ICT can improve the management of education through more efficient administrative processes including human resource management, monitoring and evaluation and resource sharing in teaching and learning and research.

In this computer age, educators and students must harness ICT to enhance their understanding of the environments and transmission and retention of knowledge for both teaching and learning processes. [19] maintained that Social Studies classrooms equipped with wireless computing devices will have more efficient, less cumbersome access to primary sources through the internet. They added that internet access helps in equalising educational opportunities allowing students regardless of socio-economic background, to utilize the myriad of sources available on net and that it has the potential for connecting students with other youths/children from around the world or experts in the field of study. Teachers and students can interact through the internet for meaningful learning to take place. [13] opined that integrating ICT into Social Studies will greatly facilitate enquiry, help students to work through problems and make rational decisions. With ICT knowledge, students will be able to develop skills to apply online critical thinking and engage in productive social interactions. ICT makes learning more interesting and meaningful to learners and it is capable of developing them into global citizens. [9] described a global citizen as one who can live and work (and learn) effectively anywhere in the world supported by a global way of life. ICT usage in Social Studies will enhance informed and active participation of students as global citizens in the global community.

The application of computer has lessened the burden of learning, teaching and administration in educational institutions. Computers have a role as a medium of instruction as they are not meant to replace the teachers but to complement classroom activities. With the use of computer in schools, a considerable improvement has been recorded in teaching and learning effectiveness. [14] stressed that pervasive perception among teachers is that computers have improved the climate for learning by increasing students' motivation in subjects for which they use computers. In support of this were [16] views that schools that have embraced technological change in instructional delivery have seen dramatic improvements consistent with school restructuring. United Nations Education, Scientific and Cultural Organisation (UNESCO, 2002) in [11] stressed that to improve learning, information and 
communication technologies must be put in place with the following conditions:

- Students and teachers must have sufficient access to digital technologies and the internet in their classrooms, schools and teacher education institutions

- High quality, meaningful and culturally responsive digital content must be available for teachers and learners

- Teachers must have the knowledge and skills to use the new digital tools and resources to help all students achieve high academic standards.

UNESCO also maintained that ICT can contribute to universal access to education, equity in education, the delivery of quality learning and teaching, teachers' professional development and more efficient education management, governance and administration.

Several studies have been carried out to ascertain the efficacy of ICT in teaching and learning as well as to determine the level of literacy and competence of teachers and students in handling technology facilities. According to Barret (2007) in [18], a meta-analysis that examined the impact of technology on students' learning showed that researchers found increased teacher-student interaction, cooperative learning and most importantly problem solving and enquiry. Among Social Studies teacher educators, [4] established that computer use in methods instruction was relatively low and that when they did use technology, it was primarily to conduct administrative details. In the study of [10], it was found that $84.7 \%$ of teachers in schools in Ekiti state did not have email addresses while $60 \%$ did not surf the internet for educational materials to update their ideas. In another study carried out on ICT and Nigeria literacy educators, [11] found that there is significant difference between the use of ICT facilities in public and private schools. One reason adduced for this finding is that literacy educators in private schools have more access to ICT facilities than those in public schools. The study added that computers and other ICT facilities are available in most private schools in the state under study unlike their public counterparts.

Findings of [5] showed that only about $9 \%$ of staff and $17 \%$ of Nigeria university students could be said to be ICT literate. The respondents which consisted of university staff and students lacked the necessary skills. Responses on items on areas of competence also revealed no competence at all by all categories of respondents. In the study of [8] carried out in one Kenya University; the findings among others established that staff members and students were not well trained in ICT. Abioye (2004) in [11] examined the perception and use of internet by adolescents in Ibadan, Nigeria. The study revealed that adolescents see the internet among others as a vital source of information and the cybercafé as the most prominent access point.

Scholars and researchers have stressed the relevance of ICT to teaching and learning and have agitated that government makes necessary technological facilities available for use of teachers and students in schools. In response to this, ICT facilities are being widely distributed in schools to enhance research and access to main stream materials while students are being heartened to put them to utmost use to express their thoughts in words, to develop creative skill and most importantly to use them for educational purpose. Information gathered by [2] indicated that very few schools out of the schools provided with computers can pride themselves on the use of internet in teaching and learning processes. The study carried out in Benin City, Nigeria by Ukpebor et al (2010) in [2] revealed that the level of internet access in schools is very poor and most schools supplied with computers cannot boast of computer laboratory while only few of them possess internet connectivity. [7] submitted that most teachers and students are not taught information computer and internet literacy skills in schools. He added that internet usage and world population statistics for March 2011 showed that $57 \%$ of the population in Africa uses the internet while few that were supplied with internet do not frequently allow students to have access to them. The findings of [2] showed that only $25.5 \%$ of the teachers access the internet to improve on their teaching and that majority of teachers use aspects of the ICT specifically computers, e-mail and internet for about one hour every week. They commented that this is grossly inadequate for teachers to this era who are expected to lead in the introduction of students to the unfathomable opportunities provided by the ICT systems.

However, inability of teachers to employ technology might be due to lack of adequate knowledge and incompetence in handling computer. [7] identified low funding of educational sector, cost of computer, low level of internet connectivity, weak infrastructure, low teledensity, lack of skills and basic infrastructure, dearth of technical support staff and teacher factor as challenges of ICT in teaching and learning. The erratic power supply usually experienced in all parts of the country make the use of ICT difficult since its facilities require regular supply for optimal functionality. Basic ICT facilities are not provided in schools. Most schools supplied computers by government cannot use them due to lack of skilled manpower and internet services. Based on the background that these studies were carried out on educators generally in their various settings, the researcher deemed it necessary to conduct this investigation to specifically determine the level of ICT competence of social studies educators and their challenges in Ekiti state.

\section{Statement of the Problem}

In Ekiti State (Nigeria), all secondary school teachers numbering about 18,000 were recently provided with personal laptops courtesy the state government. The main objective was to encourage teachers and ensure that they begin to use the facility to enhance teaching activities. With this new development, educators are expected to acquire skill in ICT usage so that they would be able to impart the knowledge into their students. However, it appears there is low level of computer/ICT literacy among educators in secondary schools. Observation shows that most of the educators are not using the facility to teach and it seems they are not willing to embrace the new technology whereas it is not 
possible to use ICT to aid teaching without being computer literate. This implies that the facility provided for them would be rendered useless, the students would not be able to develop technologically and government's hope of developing an ICT compliant educational system would be dashed. It is on this premise that this study was carried out to determine the level of Social Studies educators' knowledge and competence in ICT usage and find out what constitute barriers to adoption of ICT.

\section{Purpose of the Study}

The purpose of this study was to examine the level of knowledge and competence of social studies educators in ICT. This would eventually determine the literacy level of the educators that are supposed to impart ICT knowledge into the students. The study aimed at finding out if the educators use ICT facilities provided for them to aid teaching. Barriers to adoption of technology by the educators were also examined.

\section{Research Questions}

The study attempted to find answers to the following research questions:

1. How knowledgeable and competent are social studies educators in ICT?

2. Do the educators use ICT facilities to aid teaching?

3. What are the barriers to adoption of technology in schools?

\section{Research Hypothesis}

This hypothesis was postulated for the study:

$\mathrm{H}_{\mathrm{o} 1}$ : Gender will not have any significant difference in the level of ICT competence of social studies educators.

\section{Methodology}

This study employed a descriptive design of the survey type. The population for the study consisted all Social Studies educators in public secondary schools in Ekiti State while the sample was made up of 150 social studies educators selected through simple random sampling technique. An instrument titled ICT Knowledge and Competence of Social Studies Educators (ICTKCSSE) was used for data collection. The instrument which was a questionnaire was meant to elicit information from the respondents on how knowledgeable and competent they are in ICT and to find out if they use ICT facilities to aid teaching and learning process. The questionnaire consisted of structured items on the questions raised for the study and was a self designed and validated one. Its reliability was ensured through test-retest method using Pearson Product Moment Correlation for analysis. Reliability coefficient of 0.73 was obtained and this was considered adequate for the study. The instrument was administered on the sampled deviation. The only hypothesis postulated for the study was inferentially analysed with student t-test. The hypothesis was tested at 0.05 level of significance.

\section{Results:}

8.1. Question 1: How knowledgeable and competent are social studies educators in ICT?

Table I: Knowledge and competence of social studies educators in ICT.

\begin{tabular}{|l|l|l|l|l|}
\hline Items & A & $\%$ & D & $\%$ \\
\hline $\begin{array}{l}\text { [1]I know what the internet is } \\
\text { all about }\end{array}$ & 123 & 82 & 27 & 18 \\
\hline $\begin{array}{l}\text { [2]I use the internet for social } \\
\text { networking }\end{array}$ & 115 & 76 & 35 & 24 \\
\hline $\begin{array}{l}\text { [3]I can download desired } \\
\text { information without help }\end{array}$ & 23 & 15.3 & 127 & 84.7 \\
\hline $\begin{array}{l}\text { [4]I can save data on flash or } \\
\text { CD Rom without assistance }\end{array}$ & 38 & 25 & 112 & 75 \\
\hline $\begin{array}{l}\text { [5]I can type very well with } \\
\text { the computer }\end{array}$ & 26 & 17.3 & 124 & 82.6 \\
\hline $\begin{array}{l}\text { [6]I have a functioning } \\
\text { laptop/desktop }\end{array}$ & 133 & 88.6 & 17 & 11.3 \\
\hline $\begin{array}{l}\text { [7]I can open and work on } \\
\text { Microsoft word }\end{array}$ & 33 & 22 & 117 & 78 \\
\hline $\begin{array}{l}\text { [8]I can say that I am } \\
\text { computer literate }\end{array}$ & 24 & 16 & 126 & 84 \\
\hline
\end{tabular}

Table 1 shows that 82 and $76 \%$ of the respondents know what the internet is all about and use the internet for social networking. While $87.4 \%$ cannot browse the internet, 84.7 and $75 \%$ cannot download desired information and save data on flash drive, CD Rom etc respectively. The table also reveals that $88 \%$ of the educators have functioning laptop. Only 17 and $22 \%$ of the educators can type very well with the computer and open and work on Microsoft word while only $16 \%$ see themselves as computer literate.

8.2. Question 2: Do the educators use ICT facilities to aid teaching?

Table 2: Educators' usage of ICT to aid teaching.

\begin{tabular}{|l|l|l|l|l|}
\hline Items & A & $\%$ & D & $\%$ \\
\hline $\begin{array}{l}\text { [9]I can browse the internet to } \\
\text { search for materials to aid the } \\
\text { teaching of my subject }\end{array}$ & 19 & 12.6 & 131 & 87.4 \\
\hline $\begin{array}{l}\text { [10]I cannot use computer to } \\
\text { teach }\end{array}$ & 131 & 87.3 & 19 & 12.6 \\
\hline $\begin{array}{l}\text { [11]I prefer to use other } \\
\text { available materials such as } \\
\text { textbooks, workbooks etc }\end{array}$ & 147 & 98 & 03 & 02 \\
\hline $\begin{array}{l}\text { [12]I find it difficult to } \\
\text { integrate ICT into the } \\
\text { teaching of my subject }\end{array}$ & 129 & 86 & 21 & 14 \\
\hline
\end{tabular}

Table 2 shows that $98 \%$ of the educators prefer to use other available materials such as textbooks, workbooks etc to support teaching, $87 \%$ cannot use computer to teach and $86 \%$ agreed that they find it difficult to integrate ICT into the teaching of social studies. Only $12 \%$ of the respondents can browse the internet to search for materials to aid teaching and learning process. 
8.3. Question 3: What are the barriers to adoption of ICT in schools?

Table 3: Barriers to adoption of ICT

\begin{tabular}{|l|l|l|l|l|}
\hline Items & $\mathrm{A}$ & $\%$ & $\mathrm{D}$ & $\%$ \\
\hline $\begin{array}{l}{[13] \text { Incompetence in }} \\
\text { computer usage }\end{array}$ & 132 & 88 & 18 & 12 \\
\hline $\begin{array}{l}{[14] \text { Lack of skilled }} \\
\text { manpower. }\end{array}$ & 106 & 70.6 & 44 & 29.4 \\
\hline $\begin{array}{l}{[15] \text { Lack of internet }} \\
\text { services }\end{array}$ & 127 & 84.6 & 23 & 15.4 \\
\hline $\begin{array}{l}\text { [16]Inadequate power } \\
\text { supply }\end{array}$ & 141 & 94 & 9 & 6 \\
\hline $\begin{array}{l}\text { [17]Non provision of ICT } \\
\text { facilities in schools }\end{array}$ & 93 & 62 & 57 & 38 \\
\hline
\end{tabular}

Table 3 shows that inadequate power supply has the highest frequency of 141 (94\%) respondents followed by incompetence in computer usage with $132(88 \%)$. Other barriers in order of importance include lack of internet services (84.6), lack of skilled manpower (70.6\%) and non provision of ICT facilities in schools $(62 \%)$.

\section{Hypothesis Testing}

9.1. Hypothesis 1: There will be no significant gender difference in the level of ICT competence of social studies educators.

Table 3: t-test analysis on gender difference in ICT competence of social studies educators

\begin{tabular}{|l|l|l|l|l|l|l|}
\hline Gender & $\mathrm{N}$ & $\mathrm{X}$ & $\mathrm{SD}$ & $\mathrm{Df}$ & $\mathrm{t}$-cal & $\mathrm{t}$-tab \\
\hline Male & 67 & 2.09 & 1.63 & & & \\
\cline { 1 - 5 } Female & 83 & 2.01 & 1.14 & & 1.03 & 1.96 \\
\hline
\end{tabular}

$P<0.05 \quad$ Not Significant

Table 3 reveals that the t-calculated (1.03) is less than the critical level (1.96). This implies that the hypothesis is not rejected. There is therefore no significant difference between male and female social studies educators' level of ICT competence. Although the male educators recorded a higher mean of 2.09 against 2.01 of their female counterparts, the difference was not significant.

\section{Discussion of Findings}

This study has shown that social studies educators do not have ICT knowledge. Although, $82 \%$ of the educators know what the internet is all about, $76 \%$ use the internet for social net working. Responses on items $3(87 \%), 7(84 \%), 10(75 \%)$ show that their level of ICT knowledge as well as the use of internet for educational purpose is very low. Only $12 \%$ can browse the internet to search for materials that can enhance the teaching of their subjects. This agrees with the findings of [2] and
[10] who established that only $25.5 \%$ of the teachers access the internet to improve on their teaching and $60 \%$ of teachers did not surf the internet for educational materials to update their ideas respectively.

Although, nearly all those interviewed by the researcher in the neighbourhood claimed that they can identify all the basic parts of a computer, know the various classifications of computer and know the functions of all the basic parts of computer. That the educators can identify all the major parts of the computer could be a function of the theoretical knowledge acquired as students of computer studies in their school days. Ability to identify parts cannot ordinarily transform to skillfully using computer to aid teaching. Of all the respondents, just $16 \%$ could boldly refer to themselves as computer literate. This implies that the educators lack necessary ICT skills and are therefore not competent. This is in agreement with [5] who found that 9 and $17 \%$ of university staff and students respectively lacked necessary skills for ICT usage. Despite the fact that all the teachers were given one laptop each, $88 \%$ agree that they have functioning laptop. This is contrary to the expected response $(100 \%)$ and it is not surprising due to the findings of the researcher through oral interview that some of them gave their laptop to their children in higher institutions who have been demanding for one. Those who did not really need the laptop gave it to their children at home with the hope that they will learn how to use it and the laptop got damaged eventually.

Table two shows that $86 \%$ find it difficult to integrate ICT into teaching, $87 \%$ cannot use computer to teach while $98 \%$ prefer to use other available materials such as textbooks, workbooks etc to aid teaching. The implication of this finding is that only an infinitesimal number of educators can use technology to enhance teaching-learning process. This might not be unconnected with the fact that ICT training has not really been organised for all educators in the state. The last time such training was organised for teachers was about six years ago when the teachers did not even have laptop and very few teachers that were teaching computer studies were involved. To even use GSM network for educational purpose is not common among the educators. What could be a common practice is using phone to connect friends on face book as a way of engaging in social networking. This finding revealed that the educators have not been making use of the laptops distributed to them by the state government to enhance teaching activities.

Inadequate power supply (94\%), incompetence in computer usage (88\%), lack of internet services (84.6), lack of skilled manpower $(70.6 \%)$ and non provision of ICT facilities in schools $(62 \%)$ were found to constitute 
barriers to adoption of technology for teaching. This substantiates the findings of [7] who also found same factors as challenges of ICT. The hypothesis tested showed that there is no significant difference in the level of ICT competence of social studies educators at 0.05 level of significance. The fact that male educators had higher mean score of 2.09 against 2.01 of the females did not indicate a significant difference. Therefore the hypothesis which stated that there is no significant gender difference in the level of ICT competence of social studies educators was not rejected. This corroborates the finding of [11] who also found no significant difference between male and female educators' use of ICT facilities.

\section{Conclusion}

This study has shown that the level of ICT knowledge of social studies educators is low, that the educators lack necessary skills for utilizing computer technology to enhance teaching-learning process and that they find it difficult to integrate ICT into their lessons. Educators have significant roles to play in ensuring that learners develop competence in employing ICT for educational purpose. Inability of the educators to embrace, harness and integrate technology into teaching and learning process in this contemporary world predicts tragedy for the educational sector except a decisive step is taken by the government to salvage the situation. In order to ensure that students develop into well informed and effective citizens that can make meaningful contributions to the advancement of the society in this digital age, the use of ICT is highly imperative as the role of the educators cannot also be ignored.

\section{Recommendations}

Based on the findings of this study, it is recommended that there is need for government policy on full integration of ICT into the teaching and learning of subjects in schools especially Social Studies. Government should make computer literacy a matter of compulsion for all educators in secondary schools. This can be done by organizing training programmes and ensuring mandatory attendance of all teachers. Social Studies educators must be involved in professional development opportunities that teach them how to use computer effectively. Educators need to develop competence in using computer to access useful and meaningful information on the internet and most importantly to use it to aid teaching of Social Studies.

\section{References}

[1] Adebiyi, A.O., The development of modern information and communications technology. In K. Ajayi, S.A. Olorunsola, S.O. Adewole \& S.M. Adebo (eds) Introduction to Computer Applications and Information Technology. General Studies Unit, University of Ado Ekiti, 2010.
[2] Adeoluwa, O.V. \& Adegbola, F.F. Teachers' use of aspects of information and communication technology in south-west Nigerian secondary schools. Research in Curriculum Studies (RICS) 6 (1), 2011, pp 1-6

[3] Ajiboye, J.O., Beyond cognitive evaluation in primary social studies in Botswana: Issues and challenges. European Journal of Social Sciences. 7 (4), 2009, pp. 22-30.

[4] Berson, M. J., Mascon, C. L., Heineken, W. F. \& Coutts, C.B. Technology innovation: An examination of beliefs and practices of social studies methods faculty. The International Social Studies Forum, 1(2), 2001.

[5] Duze, C.O. Information and communication technology (ICT) in the management of education for sustainable development in Nigeria. Journal of Educational Review 4 (2), 2011, pp. 163-173.

[6] Federal Government of Nigeria. National Policy on Education. NERDC Press, Abuja, 2004.

[7] Jegede, S.A. The use of information and communication technology (ICT) in the teachinglearning process: prospects and challenges. Research in Curriculum Studies (RICS) 6 (1), 2011, pp 125-133

[8] Kessio, D.K; Kindiki, N.J., Bolt, J.M. \& Kosgei, Z.K. The challenges facing bachelor of education school based programme students satisfaction on the use of ICT: a case of moi university, Kenya. Journal of Educational Review, 4 (2), 2011, pp. 192-200.

[9] Noddings, U. Preparing our students for work and citizenship in the global age. Phi Delta Journal of Social Studies, 86 (3), 2004, pp. 197-199.

[10] Ofodu G.O. Nigerian literacy educators and their technological needs in a digital age. Journal of Educational Foundations and Management, 5 (1), 2007, pp. 22-29.

[11] Ofodu, G.O. ICT and Nigeria literacy educators: implications for sustainable development. In B.O. Ogundele, O.A. Morohunkola and J.F. Babalola (eds) Contemporary Issues in Education, Health and Sports: The Way Forward. Dept. of Human Kinetics and Health Education, University of Ibadan, 2011, pp. 170-181.

[12] Ogunsola, I. A. Information communication technologies and the effect of globalization. Twenty-first century digital slavery for developing countries-myth or reality? In electronic Journal of Academics and Special Librarianship, 6 (1-2), 2005, pp. 1-10.

[13] Oluwagbohunmi, M.F. Utilisation of information and communication technology (ICT) in the teaching of social studies in Nigerian schools. Journal of Educational Foundations and Management. 8 (1), 2010, pp. 82-90. 
[14] Penuel, W., Golan, S., Means, B.,\& Korbak, C. Silicon valley challenge 2000: year 4 report. Menlo Park, C.A.: SRI International, 2000.

[15] Provost, F. Information technology and electronic commerce. DICM Publishing, New York, 2000.

[16] Sandholtz, J.H. Ringstaff, C. \& Dwyer, D.C. Teaching with technology: creating student-centered classrooms. Teachers College Press. New York, 1999.

[17] Siray-Blatchford, J. \& Siray-Blatch Find, D.C. More than computing information and communication technology in the early. London: the British Association of Early Childhood Education, 2003.

[18] Umoru, J.O. Towards examining facilitative effect of technology on school system. Journal of the National Association for Science, Humanities and Education Research. 8 (2), 2010, pp. 86-93

[19] Van-Hover, S.D., Berson, M.J., Bolick, C.M. \& Swan, K.O. Implications of ubiquitous computing for the social studies curriculum. Contemporary Issues in Technology and Teacher Education 6 (2), 2006, pp. 5260.

[20] Wai-Kong Ng, Fengchun Miao, \& Molly Lee (2010). Capacity building for ICT integration in education. Digital Review of Asia Pacific, 2009-2010, 2010, pp. 21-46. 